\section{HEALTH CARE SEEKING BEHAVIOUR DURING TIMES OF ILLNESS: A CROSS- SECTIONAL STUDY AMONG ADULT POPULATION RESIDING IN THE SLUMS OF GUWAHATI CITY}

\author{
JUTIKA OJAH $^{\mathrm{a}}$ AND SABRINA YASMIN ${ }^{\mathrm{b} 1}$

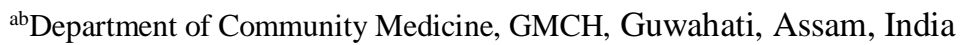

\begin{abstract}
Health seeking behaviour is critical for planning and management of health care services for the urban poor population residing in slums and other squatter settlements. To assess the health care seeking behaviour of slum dwellers of Guwahati city and its association with different sociodemographic factors. This is a descriptive cross-sectional study conducted from June to November, 2018 among 600 adults residing in 20 urban slums which is selected by simple random sampling. Out of the 600 respondents, $284(47.33 \%$ ) were males \& $316(52.67 \%)$ were females. A major portion of the respondents 190(31.67\%) belonged to the age group 20-29 yrs. During the preceding 30 days, 213(35.5\%) of the respondents fell ill and out of which $194(91.08 \%)$ respondents sought health care while $19(8.92 \%)$ did not. It was found that majority of the respondents $81(41.75 \%)$ practiced self-medication while only $66(34.02 \%)$ of the respondents sought health care from Government Health care facilities. Majority of the study participants took remedial actions during episodes of illness. However, the number of respondents who sought care from Government health care facility is less.
\end{abstract}

KEYWORDS: Slum, Health Seeking Behaviour

As per Census 2011, the urban population in India has increased from 28.6 crore in 2001 to 37.7 crore in 2011 , which is $31.16 \%$ of the total population (Rajan and Kumar, 2016). Rapid growth of industrialization has led to the increase in urban poor population owing to migration of large number of people from rural to urban areas in search of job opportunities. These migrants end up living in slums and other squatter settlements where the living conditions are extremely poor and are exposed to greater health hazards as compared to other urbanites (Suryakantha, 2017) (Musoke et al., 2014). However, the utilization of healthcare services is low despite the high disease burden. Studies have shown that only about $4 \%$ households in urban areas seek any form of OPD care from primary health care facilities (Ayushman Bharat). In spite of large number of doctors and para-professionals in urban areas, the existing health care infrastructure in urban areas is insufficient to meet the basic health care needs of growing urban poor population. Lack of information and assistance at the secondary and tertiary hospitals makes them unfamiliar to the modern environment of hospitals thus restricting their access. Above that poor economic condition restricts their access to the private healthcare facilities as well (National Urban Health Mission). Knowledge about morbidity profile and health seeking behaviour of the urban poor population is critical for planning health care services as per their needs, but this is often ignored. As a result of which, healthcare system don't get the desired acceptance \& are therefore rendered unsuccessful. The present study is intended to assess the health care seeking behaviour among the adult slum dwellers of Guwahati city.

\section{METHODOLOGY}

\section{Inclusion Criteria}

1. Adults (20-59 years of age) residing in the slums for $>6$ months.

2. Those who gave consent to participate in the study.

\section{Exclusion Criteria}

1. Critically ill individuals.

2. Those with any disability and impairment that could hinder the data collection procedure.

3. All pregnant women.

\section{Sample Size Calculation}

According to NSS $71^{\text {st }}$ round (January - June, 2014), 44\% people residing in urban areas of Assam sought health care from Government health facilities for the ailments they perceived in the last 15 days. The sample size was calculated using the formula $\mathrm{N}=4 \mathrm{pq} / \mathrm{l}^{2} \mathrm{x}$ Deff. Where, $\mathrm{p}=44 \%$, absolute precision $(\mathrm{d})=5 \%$ and 
design effect $=1.5$ the sample size was calculated to be 591.36 which was rounded to 600 .

\section{Sampling Technique}

A two stage cluster sampling design was adopted. Out of the total 99 notified slums (Slum profile survey, GMC, 2014) 20 slums were selected by simple random sampling. Subsequently, from each selected slum, 15 households were selected applying systematic random sampling.

\section{Study Tools}

Data was collected using a pre-designed and pretested semistructured schedule which had two parts:

Part 1: consist data on socio-demographic factors like age, gender, marital status, level of education, occupation and socio-economic status. Socio-economic status of the study population was recorded and classified according to Modified BG Prasad Scale.

Part 2: consist information on health seeking behaviour and utilization pattern of health care services during the time of illness. The study participants were asked if they suffered from any illness during the preceding 30 days. Only those individuals who reported history of illness were asked questions regarding health seeking behaviour. Respondents were asked if they sought health care during illness. If the answer was "yes" then type of health facility and type of medicine preferred were enquired and for those who did not seek health care during illness, reasons for the same were ascertained.

\section{OPERATIONAL DEFINITIONS}

Health care seeking behaviour is defined as an action undertaken by an individual during his/her illness to rectify the health problem. Health care seeking behaviour is defined as formal if care is sought from trained healthcare providers; informal if care is sought from members of his/her social network (i.e. family members, friends, neighbour and other trusted person).

Self-medication is defined as the use of drugs on one's own initiative to treat self recognized disorders and symptoms without consulting a trained health care provider or it is the intermittent/continued use of drugs prescribed by a physician for chronic/recurring diseases. It also includes the use of the medication of family members, friends, neighbour or as per the suggestion from an advertisement in newspapers or magazines.

\section{Data Collection Technique}

House to house visits were done and from each household one eldest adult respondent was interviewed after obtaining verbal consent. If no adult was present or the house was found locked at the time of the visit, adjacent household was visited.

\section{Data Analysis}

Data was compiled and analysed using Microsoft Excel and Instat Graph pad software. Univariate analysis was done for frequency computation. The Chi-square test and Fischer's exact test were done to determine the association between the variables and $\mathrm{p}$ value $<0.05$ was considered to be statistically significant.

\section{RESULTS}

Out of the total 600 respondents interviewed, $284(47.33 \%)$ were males and $316(52.67 \%)$ were females. Most of them 190 (31.67\%) were 20-29 years of age while only $92(15.33 \%)$ of the respondents belonged to 50-59 years age group. Around half $282(47 \%)$ of the study participants did unskilled work while $3 / 4^{\text {th }}$ of them $462(77 \%)$ were married. Socio-economic status of the study participants were determined using modified BG Prasad classification, 2018 and it was found that most of the respondents $284(47.33 \%)$ belonged to social class IV while only 16 (2.67\%) belonged to social class I.

Table 1: Socio-demographic characteristic of the study participants $(N=600)$

\begin{tabular}{|c|c|c|}
\hline Socio-demographic characteristics & Frequency (N=600) & Percentage \\
\hline \multicolumn{3}{|c|}{ Age } \\
\hline $20-29$ & 190 & 31.67 \\
\hline $30-39$ & 198 & 33 \\
\hline $40-49$ & 120 & 20 \\
\hline $50-59$ & 92 & 15.33 \\
\hline Male & Sex \\
\hline Female & 284 & 57.33 \\
\hline & 316 & 52.67 \\
\hline Illiterate & 88 & 14.66 \\
\hline
\end{tabular}


OJAH AND YASMIN: HEALTH CARE SEEKING BEHAVIOUR DURING TIMES OF ILLNESS: A CROSS....

\begin{tabular}{|c|c|c|}
\hline & 190 & 31.67 \\
\hline Primary school & 210 & 35 \\
\hline Middle school & 112 & 18.67 \\
\hline High school and above & 36.33 \\
\hline Homemaker & 218 & 47 \\
\hline Unskilled & 282 & 4 \\
\hline Semiskilled & 24 & 4.67 \\
\hline Skilled & 52 & 4 \\
\hline Unemployed & 24 & 77 \\
\hline & \multicolumn{2}{|c|}{} \\
\hline Married & 462 & 2.33 \\
\hline Divorced & 14 & 7.33 \\
\hline Widow & 44 & 13.34 \\
\hline Unmarried & 80 & 2.67 \\
\hline Social Class I & 16 & 15.33 \\
\hline Social class II & 92 & 25.67 \\
\hline Social class III & 154 & 47.33 \\
\hline Social class IV & 284 & 9 \\
\hline Social class V & 54 & \\
\hline
\end{tabular}

It was found that $213(35.5 \%)$ respondents felt sick in the preceding 30 days while $387(64.5 \%)$ did not. Out of 213 respondents, majority 194 (91.08\%) sought health care while $19(8.92 \%)$ didn't seek any care during illness. More than $1 / 3^{\text {rd }}$ of the respondents, $81(41.75 \%)$ tried self-medication while only 66(34.02\%) sought care in Government health facilities and $44(22.68 \%)$ visited private hospital. Regarding system of medicine, majority 177 (91.23\%) preferred Allopathic medicine and only 5 $(2.58 \%)$ and $3(1.55 \%)$ preferred Ayurvedic and Homeopathic medicine respectively. According to the reasons for not seeking health care during illness, majority $13(68.42 \%)$ didn't find it necessary as symptoms were not severe and for $4(21.05 \%)$ lack of money was the reason for not seeking care. Out of the 66 respondents who sought care in Government health care facility, availability of low cost was the most common reason for majority $53(80.30 \%)$ of them. .And out of the 147 study participants who didn't seek care in Government health facility, long waiting hours was the reason for majority $97(65.99 \%)$ of them. Significant association was found between gender, education and socio-economic status of the study participants with their health-seeking behaviour during illness $(\mathrm{p}<0.05)$.

Total no study participants $(\mathrm{N}=600)$

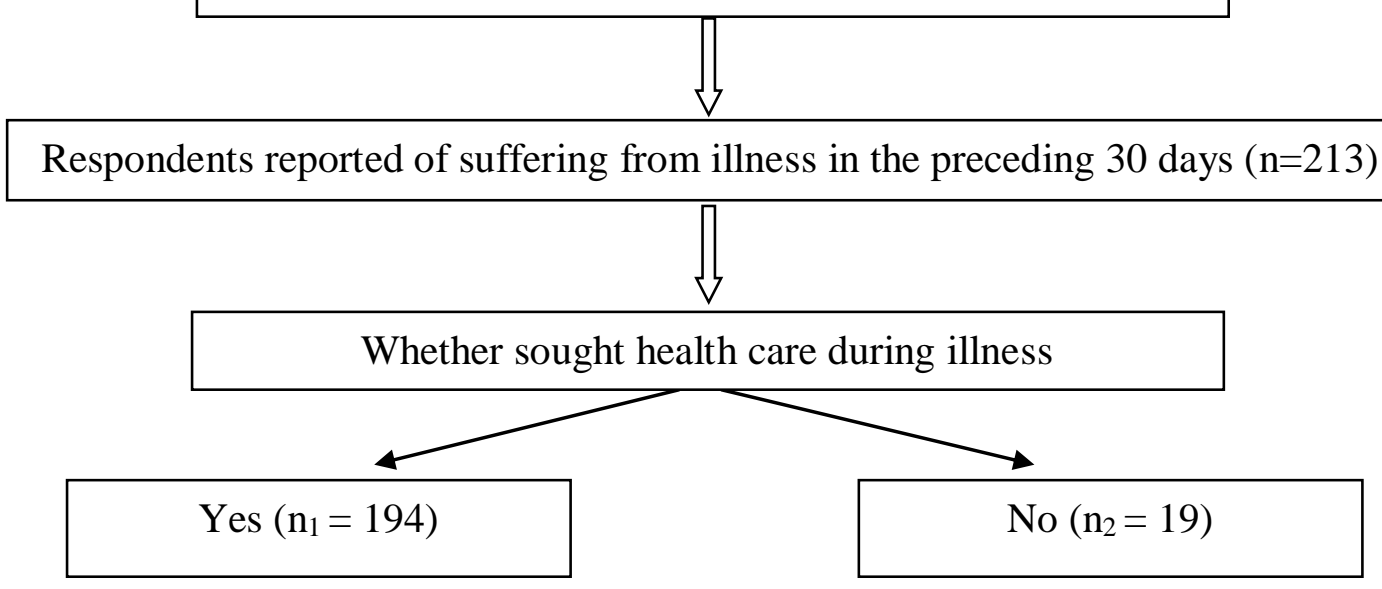

Figure 1: Flowchart showing number of respondents who sought and who didn't seek healthcare during period of illness in the preceding 30 days. 
OJAH AND YASMIN: HEALTH CARE SEEKING BEHAVIOUR DURING TIMES OF ILLNESS: A CROSS....

Table 2: Distribution of respondents based on what remedial actions they took during illness.

\begin{tabular}{|c|c|c|}
\hline Remedial action taken during illness & Frequency $\left(\mathbf{n}_{\mathbf{1}}=\mathbf{1 9 4}\right)$ & Percentage \\
\hline Went to Govt. Health Care Facility & 66 & 34.02 \\
\hline Went to Private Doctor/Hospital & 44 & 22.68 \\
\hline Tried self-medication & 81 & 41.75 \\
\hline Went to traditional healers & 4 & 2.06 \\
\hline Tried home remedies / non drug self treatment & 5 & 2.58 \\
\hline
\end{tabular}

* Multiple Responses

Table 3: Distribution of respondents based on their preference of system of medicine during illness

\begin{tabular}{|c|c|c|}
\hline System of Medicine & Frequency $\left(\mathbf{n}_{\mathbf{1}}=\mathbf{1 9 4}\right)$ & Percentage \\
\hline Allopathic & 177 & 91.23 \\
\hline Ayurvedic & 5 & 2.58 \\
\hline Homeopathic & 3 & 1.55 \\
\hline Herbal & 9 & 4.64 \\
\hline
\end{tabular}

Table 4: Distribution of respondents based on reasons for not taking any action

\begin{tabular}{|c|c|c|}
\hline Reason & Frequency $\left(\mathbf{n}_{2}=\mathbf{1 9}\right)$ & Percentage \\
\hline Didn't find it necessary as symptoms were not severe & 13 & 68.42 \\
\hline Lack of money & 4 & 21.05 \\
\hline Long waiting hours & 3 & 15.79 \\
\hline Waited for spontaneous recovery & 3 & 15.79 \\
\hline
\end{tabular}

Table 5: Distribution of respondents based on reasons for utilization and non-utilization of Government health facility during illness

\begin{tabular}{|c|c|c|}
\hline $\begin{array}{c}\text { 1) Reasons for utilization of Government health facility } \\
\text { during illness }\end{array}$ & $\begin{array}{c}\text { Frequency } \\
\left(\mathbf{n}^{*}=\mathbf{6 6}\right)\end{array}$ & Percentage \\
\hline Low cost & 53 & 80.30 \\
\hline Financial Constraints & 24 & 36.36 \\
\hline Govt. health care facility is located nearby & 10 & 15.15 \\
\hline Availability of good quality treatment & 7 & 10.60 \\
\hline 2) Reason for non-utilization of Government health facility \\
during illness & $\begin{array}{c}\text { Frequency } \\
\left(\mathbf{n}^{* *}=\mathbf{1 4 7}\right)\end{array}$ & Percentage \\
\hline Waiting time is more & 97 & 65.99 \\
\hline Non availability of free drugs \& diagnostic services & 41 & 27.89 \\
\hline Location of the facility is far away from home & 20 & 13.61 \\
\hline No effective treatment given & 23 & 15.65 \\
\hline
\end{tabular}

*Multiple responses 
OJAH AND YASMIN: HEALTH CARE SEEKING BEHAVIOUR DURING TIMES OF ILLNESS: A CROSS....

Table 6: Socio-demographic factors affecting the health seeking behaviour of the respondents during illness

\begin{tabular}{|c|c|c|c|c|}
\hline \multicolumn{2}{|c|}{ Sociodemographic factors } & \multicolumn{2}{|c|}{$\begin{array}{c}\text { Sought health care service during } \\
\text { illness }\end{array}$} & \multirow{2}{*}{$\begin{array}{l}\chi^{2} / F \text { test } \\
\text { (p value) }\end{array}$} \\
\hline sociodem & apme ractors & $\begin{array}{c}\text { Yes } \\
\left(n_{1}=194\right)\end{array}$ & $\begin{array}{c}\text { No } \\
\left(\mathbf{n}_{2}=19\right)\end{array}$ & \\
\hline \multirow{2}{*}{ Gender } & Male & 71 & 15 & \multirow{2}{*}{$(\mathrm{p}<0.05)$} \\
\hline & Female & 123 & 4 & \\
\hline \multirow{4}{*}{ Educational status } & Illiterate & 7 & 9 & \multirow{4}{*}{$\begin{array}{c}54.686, \mathrm{df}=3 \\
\quad(\mathrm{p}<0.05)\end{array}$} \\
\hline & Primary school & 42 & 7 & \\
\hline & Middle school & 84 & 1 & \\
\hline & High school and above & 61 & 2 & \\
\hline \multirow{5}{*}{$\begin{array}{l}\text { Socio-economic } \\
\text { status }\end{array}$} & Social class I & 5 & 1 & \multirow{5}{*}{$\begin{array}{c}9.584, \mathrm{df}=4 \\
(\mathrm{p}<0.05)\end{array}$} \\
\hline & Social class II & 19 & 3 & \\
\hline & Social class III & 59 & 7 & \\
\hline & Social class IV & 99 & 4 & \\
\hline & Social class V & 12 & 4 & \\
\hline
\end{tabular}

\section{DISCUSSION}

This study was conducted in the slums of Guwahati city with the aim to assess the health care seeking behaviour of adult population and its association with different sociodemographic factors. In the study out of 600 respondents, $47.33 \%$ were male and $52.67 \%$ were females which are in accordance with the findings of study conducted by Aleemi et al., 2018. Majority (77\%) of the study participants are married \& most of them belong to the age group of 20-29 years (31.67\%) and socio-economic class IV $(47.33 \%)$. The age distribution, marital status and socio-economic status correspond with the findings of the study conducted by Patil et al., 2016 in Dharavi, Mumbai. It was found that out of 600 respondents, $213(35.5 \%)$ felt sick in the preceding 30 days. Among those who felt ill, $91.08 \%$ sought health care during their illness while $8.92 \%$ didn't. Similar findings were found in the study conducted by Mahejabin et al., 2015 in slums of Dhaka city. Majority of the study participants, $41.75 \%$ in our study tried self-medication during illness which is similar to the findings of other studies conducted by Velhal and Durgawale, 2016 in slums of Karad town in Maharashtra and Siddiqui et al., 2011 in urban slum areas of Karachi. Majority of the respondents in our study preferred seeking care from non Government sources like private clinic/hospital, traditional healers or tried self-medication and home remedies which is in accordance with the study conducted by Banerjee et al., 2012. Allopathic medicine was preferred by majority (91.23\%) of the respondents in our study which corresponds with the findings of other studies conducted in the slums of Mumbai by Singh and Kalaskar, 2017. According to the reasons for not seeking health care, majority didn't seek treatment because they didn't find it necessary as the symptoms were not severe. A study conducted by Karanjekar et al., 2014 in the slums of Aurangabad city observed similar findings. The main reason for majority of the study participants (80.30\%) seeking health care from Government health care facility was low cost which is in accordance with the findings of the study conducted in slums of Delhi by Khokhar et al., 2003. In the study significant relationship was observed between gender, education and socio-economic status of the slum dwellers with their health seeking behaviour during illness $(p<0.05)$. Similar findings were observed in the studies conducted by Kumar and Mishra, 2017 in Varanasi and Gill et al., 2015 in the slums of Amritsar city.

\section{CONCLUSION}

The study findings show that majority of the respondents took action during illness to rectify their health problem. However, the respondents preferred non Government sources for seeking health care indicating low utilization of Government health care services. The main reason for non utilization of Government health care services was long waiting hours.

\section{REFERENCES}

Ayushman Bharat, Comprehensive Primary Health Care through Health and Wellness Centers: Operational Guidelines; pp-1. Available at https://ab-hwc.nhp.gov.in 
Aleemi A.R., Khaliqui H. and Faisal A., 2018. Challenges and Patterns of seeking primary healthcare in slums of Karachi: A Disaster lurking in urban shadows. Asia Pacific Journal of Public Health, 30(5): 1-12.

Banerjee A., Bhawalkar J.S., Jadhav S.L., Rathod H. and Khedkar D.T., 2012. Access to health services among slum dwellers in an industrial township and surrounding rural areas: A rapid epidemiological assessment. Journal of Family Med. Prim. Care, 1(1): 20-26.

Gill K.P., Devgun P. and Mahajan S.L., 2015. Morbidity pattern and health seeking behaviour of women in reproductive age in slums of Amritsar city (Punjab), India. International Journal of Community Medicine \& Public Health, 2(2): 112-115.

Karanjekar V.D., Gujarathi V.V. and Lokare P.O., 2014. Socio-demographic factors associated with health seeking behaviour of chest symptomatic in urban slums of Aurangabad city, India. International Journal of Basic and Applied Medical Sciences, 4(1): 173-179.

Khokhar A., Garg S. and Singh M.M.C., 2003. Healthcare service utilization for RTIs/STIs and diarrheal diseases: A study amongst slum dwellers in Delhi. Health and PopulationPerspectives, 26(2): 59-66.

Kumar S. and Mishra N., 2017. A study of morbidity pattern and health seeking behaviour in urban slum population of Varanasi, India. International Journal of Advanced Research, 5(9): 1204-1210.

Mahejabin F., Parveen S. and Begum R., 2015. Disease Pattern and Health seeking behaviour of slum dwellers in Dhaka city. International Journal of Medical and Health Research, 1(2): 04-08.
Musoke D., Boynton P., Butter C. and Musoke M.B., 2014. Health seeking behaviour and challenges in utilising health facilities in Wakiso district, Uganda. African Health Sciences, 14(4): 10461055.

National Urban Health Mission: Framework for implementation October 2012; pp 3-4. Available at http://www.pbhealth.gov.in $>\mathrm{NUHM}$

Patil S.P., Parbhankar S.S., Bansode-Gokhe S.S., Shelke P.S. and Singh R.D., 2016. Study of health seeking behaviour and its determinants among attendees of urban health center, Dharavi, Mumbai, India. International Journal of Community Medicine \& Public Health, 3(7): 1856-1861.

Rajan A.A. and Kumar K.M., 2016. Urban health and wellness in Indian context - A strategic approach in urban design. Procedia Technology, 24: $1750-1757$.

Siddiqui M.S., Siddiqui M.K. and Sohag A.A., 2011. Health seeking behaviour of the people; knowledge, attitudes and practices (KAP) study of the people of urban slum areas of Karachi. Professional Med. J., 18(4): 626-631.

Singh S. and Kalaskar S., 2017. Health care seeking behaviour and utilization pattern in an urban slum of Mumbai: A cross sectional study. International Journal of Current Research, 9(4): 49342-49345.

Suryakantha A.H., 2017. Community Medicine with Recent Advances. New Delhi: Jaypee Brothers Medical Publishers (P) Ltd. p.738-756.

Velhal V.G. and Durgawale P.M., 2016. Health seeking behaviour of urban slum dwellers in Karad- A town in Western Maharashtra. International Journal of Science and Research, 5(11): 11-15. 